\title{
Rethinking the Role of Indigenous Law Community in Managing Indigenous Forest in Jambi Province
}

\author{
Taufik Yahya ; Fauzi Syam ${ }^{\star \star}$ \\ * Faculty of Law, Jambi University \\ taufik_yahya@unja.ac.id

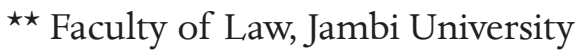 \\ fauzisyamjambi65@gmail.com
}

\begin{abstract}
This article examines the synchronization of regulations on forestry, green farming, and mining sectors along with their implementation through which the writer wished to evaluate the role of indigenous law community in managing indigenous forest in Jambi Province. It is learned that the Act Number 41 year 1999 concerning Forestry has not provided certainties for the indigenous law community in managing forest in Indonesia. Meanwhile, the Act Number 6 year 2014 on Village stresses out that there is a specific acknowledgement about local customary villager as a part of indigenous law community. In the Act on Village, the establishment of indigenous law community is strongly stated in provincial government regulations. This paradox has brought a bad consequence to indigenous forest that is managed by the indigenous law communities in Jambi Province.
\end{abstract}

Keywords: Indigenous Law Community, Managing, Indigenous Forest.

\section{A. Introduction}

Rooms for local community to manage indigenous forest have been stipulated in the Act No. 41 Year 1999 along with their implemen- 
tation, yet they have not been utilized optimally. Various attempts which support the existence of law community in managing forest have not been stronger than central/provincial governments' interests and, than those of forest and green farming companies or industries. Nevertheless, the existence of indigenous law community ${ }^{1}$ and indigenous forest has been questioned again. As a result, many initiative efforts which have been made to support the existence of law community and indigenous forest in the era of regional autonomy have just been addressed more for the benefits of ordinary community and non-government organization (NGO).

This becomes more worrying and serious since the Act on Forestry have been used as a legal basis to confirm that indigenous forest in Indonesia is categorized into State Forest and Title Forest. State forest is any forest which is located in the state land area on which not charged with land title. This is in line with the Act Number 5 Year 1960, where forests are categorized into several types, including any other types of forests with the so called indigenous forest, indigenous forest, and so forth. By owning and categorizing forest which has been owned by indigenous law community into state owned forest, this shows that the state has overtaken the rights to possess and manage all forests in the country.

The establishment of indigenous forest that has been owned and managed by indigenous law community faces a serious legal problem. On one hand, there is a legal approval for indigenous forest and

1 The term "indigenous law community" refers the so called term of masyarakat hukum adat (Adat Rechtsgemeenschap). This specific Indonesian term is not really well known by non-Indonesian countries and, therefore, sometimes lead to misinterpretation on it when it is translated it into English. Some prefers the original and avoids translation, i.e. "masyarakat hukum adat" such as Yance Arizona, "Masyarakat Hukum Adat before the Constitutional Court: an Analyze on Paul Scholten's Interpretation Method in Contemporery Judicial Development in Indonesia," in http: / / www. paulscholten.eu/research / article/ masyarakat-hukum-adat-before-theconstitutional-court/, accessed in May 2018. Some others tries to combine it., adat law community. The writer is using indigenous law community elsewhere in this article, referring to a translation on the Act Number 41 Year 1999 on Forestry. 
indigenous law community. On the other hand, however, this is hard to be implemented because indigenous forest is conceptually part of state forest. As a result, the government either central or local should have determined, in direct ways, the forest areas that have been managed and utilized from generation to generation by indigenous law community. In total, the area of forest in Indonesia is 131.2 million hectares. Some of these areas have been provided for Industrial Plantation Forest (HTI) 9.8 million hectares, Exploration and Coal and Oil/Gas Mining Industries 3.2 million hectares, and Green Farming 5.2 million hectares.

Rights for Managing Forest (HPH) have been provided for a total area of 25 million hectares and this is in the process of releasing for administrative areas of 12.35 million hectares ${ }^{2}$. In addition, there are still 33,000 villages located in forest area. Conflicts may potentially happen in the future. This is because people feel that they have rights for managing and owning forest, yet at the same time, they have to face a paradigm that the state will have to force them out of the area. ${ }^{3}$

The judges of Constitutional Court of the Republic of Indonesia, on May 2013, granted a legal approval for a legal material examination proposed by the AMAN or Aliansi Masyarakat Adat Nusantara (National Alliance of Indigenous Peoples of the Archipelago), Indigenous people of Kuntu in Riau Island, and Indigenous people of Cisitu Banten to reexamine the State Regulation Number 41 Year 1999 concerning indigenous forest in the state forest. This was a great success over the struggle of AMAN and several law communities in Indonesia for several years. Based on this approval, indigenous forest is no longer seen as the state forest. Rather, it becomes the forest that can be used by indigenous law community.

Article 1 point 6 which firstly states "Indigenous forest is state's forest situated in indigenous law community area" truly contradicts to the 1945 Constitution of the Republic of Indonesia and this has

2 Annual Report of Forestry Ministry in Forestry Statistics, 2012

3 Musri Nauli, Understanding (reverse) SBY's sentences, Paper Opinion, Jambi Express, Monday, 17 June 2013 
no legal rights as long as it is not seen as "Indigenous forest is state's forest situated in indigenous law community area". This means that since 16 May 2013, indigenous forest has no longer been a part of state forest but as a forest area which can be managed and used by indigenous law community.

Although this state regulation cannot be back dated, the approval of its interpretation has given enough support for indigenous law community to get their rights back for indigenous forest. They have very strong legal basis to earn back all forest areas that have become their own rights as a law community as a result of the implementation of Article 1 point 6 in forestry activity in Indonesia.

Some problems in the level of community have something to do with the Indonesian Constitutional Court verdicts or decisions. First, the Constitutional Court has separated indigenous forest and state forest and there are still other regulations and their implementation practices that show their contradiction. Second, many people believe that the Constitutional Court verdicts are the only legal basis for managing indigenous forest, so that they can be implemented accordingly. Furthermore, the existence of indigenous law community still needs approval from local government. Next, the approval of indigenous law community is an important requirement as a condition for managing indigenous forest.

Based on the above description, some problems that are used as the focus of analysis in this article include: first, the non-synchronization aspect between forest regulations and other regulations such as those in green farming, mining and their implementation rules; second, the uncertainties of the existence of indigenous law community in the management of indigenous forest; third, the uncertainty of the existence of indigenous forest area itself.

Based on the above background, the article addressed two questions formulated as follows:

1. How to manage and organize the existence of indigenous law community in Indonesia?

2. How to establish the existence of indigenous law community in managing indigenous forest? 


\section{B. Literature Review}

\section{Indigenous forest}

The conception of customary law cannot be separated from the conception of forest itself. The conception of forest has actually been approved to affect the regulations about forest and they are followed by the utilization pattern of forest.

Some doctrines about forest which are very influential so far include: ${ }^{4}$ first, the doctrines of timber primacy which describes the approval of ideology in its relation to "wake theory", and this states that all other goods and services obtained from forest such as timber should follow the main products. The content of this conceptual theory is regarded as inadequate and does not give any options for the variety of usefulness and management of forest. Second, the doctrines of sustained yield is viewed as the core of forestry science which is based on "forest ethics", helping to avoid the optimization of one side profits and exclusiveness as well as appreciating what forest has been providing for the sake of human life.

According to Hariadi Kartodiharjo, the above doctrines confirm a discourse that forest management should be as follows:

a. Does not recognize the variety of aims of forest management, meaning that it does not appreciate various practitioners, but in reverse, it does give an evaluation about the existence of forest with the economic value of timber as the first priority.

b. The strength of conservative building seems to be reluctant to receive any social and institutional interests and therefore wants a social condition which is guaranteed by social authority and strong state roles.

c. With reference to learning natural laws and forest, community feel that they do not have any different interest towards forest, but forest does have various functions for community, and as a

4 Qluck, P. 1987. Social Values in Forestry. Ambio, 16(2/3); p. 158-160 cited in Hariadi Kartodiharjo. Hutan Negara Di Dalam Wilayah Masyarakat Hukum Adat: Doktrin, Fakta Dan Implikasinya Bagi Kelestarian Hutan, Bogor: Forestry Faculty, IPB. 
result, people are frequently seen as an object rather than as a subject, and forest, in reverse, is often seen as a subject rather than as an object. People tend to think critically about democracy and freedom, but they do not believe on pluralism interests and at the same time stress on capitalism.

d. Forest conservation is associated with synchronizing all forest functions for public interests so that decisions of forest utilization and management for individual or group choices are ignored and forest conservation has been forced to cater for forest owners with various regulations. ${ }^{5}$

Indigenous forest as a part of state forests should be regarded as the government efforts to provide rights directly to the state to make policy and regulations for forest practices and management. Community interest as a part of people rights to own and use land forest and its natural resources has been put aside and seems to be much less powerful compared with the government authority. People cannot do more than expected because it has been stressed that indigenous forest is part of state forest. By state forest, it means that all forests which are lying on state land areas are not given any rights to people to own and manage them. By putting indigenous forest into state forest areas, people will never have rights and interests to own a certain areas of indigenous forests because it will not be legally approved or granted. This has led to many conflicts which involve local indigenous law community, central/local governments and industries or companies.

\section{Indigenous law community}

The term Indigenous law community is firstly stated in the Article 18 B point (2) in the National Constitution 1945, "The State recognizes and respects traditional communities along with their traditional customary rights as long as these remain in existence and are in accordance with the societal development and the principles of the Unitary State of the Republic of Indonesia, and shall be regulated by

5 Ibid. 
law." This chapter is a constitutional basis which guarantees all community rights to grow and develop in local, regional, and national levels in the frame of national united Republic of Indonesia, and this also shows the state's legal guarantee for local people rights for managing and owning natural resource within the country.

Indigenous law community as a subject of law is a law institution and it is said to be "Gemeenschaap" meaning a law firm made naturally due to social, economic, and political developments but not "verenigingen" made intentionally for the sake of its personal members. As a law firm, indigenous law community has social public rights.

In a general perspective, customary community is equal to ethnicity, for example, Padang/Minang, Punan, Kenyah, Melayu, and Orang Rimba. But what make them differs from other ethnics? Aliansi Masyarakat Adat Nusantara/National Alliance of Indigenous Peoples of the Archipelago (AMAN) describes indigenous people/community as a group of people/community who shares same hierarchical and tribal history for a long time in a particular area and they have several things in common such as values, ideology, economy, politics, culture, social and habitats for living. In a simple perspective, it can be said that customary community/ people are law bound community in terms of ethnicity and place of living. In connection with customary law, it is apparent that they still opt to follow and believe in the customary life and they still stick to this as the main principle guidance in their life practices. However, it is still obvious that although most of these principles are not printed they still remember all of these rules or principles. ${ }^{6}$

The establishment and respect to the faction of indigenous law community reflect that their existence as a community that have rights, interests, and historical developments are legally recognized, and this includes their rights to use and own land forests as well as their rights to determine their social relationships within their community.

6 Warta Kebijakan, Masyarakat Hukum Adat, CIFOR, Bogor, Edition 2, February 2002 . 


\section{The Management of Indigenous Law Community Existence in Managing Indigenous Forest in Indonesia}

Indigenous law community is a part of community in which their existence is approved in the National Constitution 1945. In Article 18 $\mathrm{B}$, it is stated:

1. The State shall recognize and respect entities of regional administration that possess a specificity or a distinctiveness that are to be regulated by law.

2. The State shall recognize and respect, to be regulated by law, the homogeneity of societies with customary law along with their traditional rights for as long as they remain in existence and in agreement with societal development and with the principle of the Unitary State of the Republic of Indonesia.

As a basic constitution, the Article $18 \mathrm{~B}$ above is further described in the Act or State Regulations. However, until 2014 there has not been any regulation which rules law community in Indonesia. In point (2) of the above Article, it is implied that there will be further regulations to accommodate this case. Yet all is unclear until present. Even the regulations of indigenous law community in some legal documents such as in Forestry Law, it is clear that the existence of indigenous law community is still unclear, not to mention all rights preserve to them.

One of the rights bound to indigenous law community is the right to manage and own indigenous forest. For indigenous law community, indigenous forest is their communal rights to which they operate from generation to generation. In the Act on Forestry, the existence of indigenous law community is the main requirement for managing and using indigenous forest. For short, indigenous forest can only be used and managed by indigenous law community.

\section{The Act Number 41 Year 1999 Concerning Forestry}

The Act or State Regulation number 41 Year 1999 about Forestry prescribes indigenous law community in their attempts to manage indigenous forest. Article 67 stated: 
(1) Indigenous law community shall if any and still acknowledged shall be entitled to:

a. collect forest produce to fulfill daily needs of relevant customary law community;

b. manage forest according to the prevailing indigenous law and not in-contravention of the law; and

c. obtain empowerment for welfare improvement.

(2) Affirmation of existence and extinction of indigenous law community as referred to in paragraph (1) shall be stipulated by Regional Regulation.

(3) Further provisions as referred to in paragraphs (1), and (2) shall be stipulated by virtue of a Government Regulation.

When one tries to look closely at the explanation of Article 67, indigenous law community means that they come from small group members in society in a specific customary area, and they have their own hierarchical structure, customary law, and traditions which they still stick to in their daily life practices. In managing and using indigenous forest, the existence of indigenous law community must be proved.

Factors of the indigenous law community existence that need to be approved according to the explanation of Article 67 point (1) have something to do with the form of small group community (rechtsgemeenschap) which is still available, also social organization in the form of customary leaders, clear indigenous forest areas, law or legal authority especially customary court and these are still followed. Lastly, they still get revenue from forest practices in the surrounding forest areas to cater for their living needs.

\section{The Act Number 6 Year 2014 about Village}

Article 1 point (1) states:

The village is a village and traditional village or called by other names, hereinafter called the Village, is a unit of community that has boundaries with the authority to regulate and manage the affairs of government, the 
interests of local communities based on community initiatives, the right of the origin, and / or traditional rights recognized and respected in the system of government of the Republic of Indonesia.

This Article gives an opportunity for indigenous law community to get a concrete approval from the government. This means that the existence of indigenous law community has been established through the state regulations in Indonesia. Consequently, the organization of the state regulations requires further local certainties for the implementation and this includes state regulations and both local and regional regulations.

In this Act, the organization of customary village is prescribed particularly in Chapter XIII, starting from Article 96 to Article 111. Article 96 states, "Government, Provincial Government, and Local Government District / City structuring law community unit and is set to be the Village People." This regulation is not found in the previous village state regulations and neither in The Act Number 32 Year 2014 concerning Local Government.

In juridical terms, the organization of Customary Village in the Act Number 6 Year 2014, has undergone a significant improvement and it is much better than the previous Act Number 23 Year 2014. Even, it is better if compared with the Act Number 41 Year 1999 concerning Indigenous law community in its relation to indigenous forest management.

The existence of indigenous law community in the State Law about Village can be used as a basis for the establishment and for the indigenous forest management, as prescribed in Article 67 point (2) The Act No. 41 Year 1999. Moreover, Article 97 point (2) of the Village Regulation gives law "softening" about the existence of indigenous law community. This softening applies particularly to the area of customary law just like the previous regulations.

\section{The Existence of Indigenous Law Community and Indigenous Forest in Managing Indigenous Forest in District Areas of Jambi Province}

In order to manage indigenous forest, the existence of indigenous 
law community needs to be established through local government regulations. The establishment should be based on criteria of indigenous law community existence as described previously. According to Maria Sumardjono, in its simple language, and to see its criteria and identity to determine indigenous law community, they have rights as follows:

1. There is indigenous law community that fulfills particular identity for customary rights subject.

2. There is area/land with particular boundaries as lebensraum (living space) that is the object of customary rights.

3. There is right for indigenous law community to do certain actions or practices related to land areas, other natural resources, and the Actions. ${ }^{7}$

The settings of indigenous forest and the existence of forest law community in the Act about Forest, as well as customary village in the Act about Village can be used as a basis for its establishment. Article 67, the Act about Forestry is a good example of the preconditioned approval of indigenous law community existence in Indonesia. These conditions are: first, the community is still in the form of small group community. Second, there is an institution in the form of law authority. Third, there is a clear customary area. Fourth, there is institution legal system, especially customary court which is still followed. Fifth, there is still revenue from forest practices that they receive to cater for their living needs. These five conditions should be proved. To prove them, identification, verification, and analysis are required.

If all five conditions can be proved, then the establishment process can be done through local government regulations. However, the specific location is not mentioned, it can be in the level of District of Province. As it is known that based on The Act Number 12 Year 2011 on the making of regulations, there are regulations of either in District or Province levels. Here are the explanations of Article 67:

7 Maria Sumargono, cited by Martua Sirait, Chip Fay and A. Kusworo, Bagaimana Hak-Hak Masyarakat Hukum Adat Dalam Mengelola Sumber Daya Alam Diatur? ICRAF, Lampung, 2000, p. 8. 
Point (1)

Indigenous law community existence is approved, and according to its condition, they should fulfill the following criteria:

a. The community is still in the form of small group members (rechtsgemeenschap);

b. There are institutions in the form of customary authorized organizations;

c. There is a clear customary law area;

d. There are structures and legal institution, especially customary court that are still followed; and

e. The community still receives revenue from forest management practices to cater for their living needs.

Point (2)

Local government regulations are designed based on research recommendations conducted by customary law experts, local people recommendations, and the recommendations of all local community senior group members, and other relevant institutions and parties.

Point (3)

Government regulations consist of certainties as follows:

a. Mechanism for research,

b. All parties involved,

c. Research materials, and

d. Evaluation criteria of the indigenous law community existence.

According to Martua Sirait et al, all the above conditions should not be completely fulfilled, and that gives clues that customary rights for managing land forest and all natural resources in the area of customary community still exist. These criteria cannot be seen as the community boundary as said not to be customary community, but they will help policy makers to accept the existence of a certain cus- 
tomary community. ${ }^{8}$ Indigenous law community needs real rights which are specific in nature. These rights cannot be transferred to other communities so that the cultural identity and rights will receive enough concerns and protection from the government as stated in the National Constitution 1945.

After independence period, the state constitution has confirmed the state approval to indigenous law community along with their rights as known in an international convention, and this needs to be conceptually and effectively determined. An international juridical approval can be found in an International Labor Organization (ILO) convention in 1969 with the team of Indigenous and Tribal Peoples in Independent Countries.

For Article 67 and its explanation, the National Constitutional Court (MK) of Indonesia, in its Verdict No. 35/PUU-X/2012 states that the state will change the word "as long as they still exist" with "as long as they are still alive" and in the term of "mutatis mutandis" this can be seen in Article 4 point (3). Based on this National Constitutional Court verdict, the establishment of indigenous law community is done through local government regulations. These regulations are followed by District Government regulations.

When connected to The Act or State Regulation Number 6 Year 2014 about Village, there are articles which organize Customary Village that have been established through District Government regulations. Here is the main explanation (point 1) of this regulation:

The diversity of characteristics and village types, or whatever they are well known in other names, this will not become an obstacle for founding fathers of the villages to put their decision for the united nation. Although it must be realized that in a united nation there are homogeneousity, but the Unitary Nation of Indonesian Republic sticks to grant approval and guarantee to the existence of law community unity and the unity of indigenous law community along with their traditional rights.

With the combination of the functions of self-governing community and local self-government, it is hoped that customary law, which has long been a part of village areas, can be well organized so

$8 \quad$ Ibid 
that it appears to be village and Customary Village. These village and Customary Village, basically, have almost the same functions. The differences lye on some aspects such as in the implementation of historical or derivational rights, particularly in the social conservation of Customary Village, the management of customary areas, customary peace court, security maintenance of the indigenous law community, and the management of government practices which are made according to the original structures.

The unity of indigenous law community is made in accordance with three main principles: genealogy, territorial, and the combination of the two (genealogy and territorial). The unity of Indigenous law community in this The Act is made based on the combination of genealogy and territorial aspects. In this respect, the state approves and respects the unity of indigenous law community along with their traditional rights as long as they are still alive and run according to the principles of the United Nation of Indonesian Republic, a few examples are: huta/nagori in North Sumatera, gampong in Aceh, nagari in West Sumatera, marga in Southern Sumatera, tiuh or pekon in Lampung, desa pakraman/desa adat in Bali, lembang in Toraja, banua and wanua in Kalimantan, and negeri in Maluku.

However, because the unity of indigenous law community which has been determined as Customary Village runs the aspect of local self-government, there are absolute conditions to be fulfilled these are: there must be a clear area with clear geographical boundaries; there must a government; and other structures within the indigenous law community such as sense of living together, welfare, and structure of customary government.

Conditions and mechanism of the establishment of indigenous law community are described in The Act of Village in Article 97 as follows:

(1) Determination of Indigenous Village referred to in Article 96 are eligible:

a. unity of traditional society with a real traditional rights is still alive, whether they are territorial, genealogical, or functional; 
b. unity of traditional society with traditional rights deemed in accordance with the development of society; and

c. unity of traditional society with traditional rights in accordance with the principles of the Republic of Indonesia.

(2) Unity of traditional society with surviving traditional rights referred to in paragraph (1) letter a must have at least the area and meet one or a combination of elements of existence:

a. society that citizens have a feeling shared in the group;

b. traditional governance institutions;

c. wealth and / or custom objects; and / or

d. the norms of customary law

(3) The unity of indigenous law community along with their real traditional rights and as long as they are still alive as stated in point (1) letter $\mathrm{b}$ must be viewed according to community development if they fulfill the following: the unity of traditional society with traditional rights referred to in paragraph (1) letter $b$ is deemed in accordance with the development of society if:

a. existence has been recognized under the law applicable as a reflection of the development of values that are considered ideal in today's society, both laws are general and sectoral; and

b. The substance of the traditional rights recognized and respected by the community unit concerned citizens and the wider community and not in conflict with human rights.

(4) An entity traditional society with traditional rights referred to in paragraph (1) letter $\mathrm{c}$ in accordance with the principles of the Unitary Republic of Indonesia if the law community unit does not interfere with the existence of the Republic of Indonesia as a political entity and the entity which:

a. not threaten the sovereignty and integrity of the Unitary Republic of Indonesia; and

b. substance of customary law norms appropriate and not contrary to the provisions of the legislation.

Looking at Article 97 above, it is obvious that customary village 
is part of indigenous law community that have owned a certain area of living, rights, governmental systems, and indigenous law community. The structure of their life, government practices, and development are done based on the existing customary law or any other laws that they have long been practicing in the community. According to Article 98 point (1), "Customary Village is defined by local or District Government Regulations”.

If linked to regulations about law community in their relation to indigenous forest management such as The Act or State Regulation Number 41 Year 1999 and the Verdict of the Constitutional Court of the Republic of Indonesia (MK) Number 35/PUU-X/2012 about the management of Customary Village within The Act of Village, thus: First, the organization of Customary Village is a follow up of the Verdict of the Constitutional Court (MK) Number 35/PUU-X/2012 as stated in the general explanation point 4 . Second, the similarity of mechanisms and conditions of indigenous law community in Article 67 of Forestry State Law and Article 97 of Village The Act, that is through the process of identification, verification, and establishment. Third, types of laws that concern with approval ${ }^{9}$ and establishment ${ }^{10}$, should be done through local or district government regulations. However, the Act about Forestry and the Verdict of the Constitutional Court (MK) do not mention anything about either local or district or provincial government regulations. Meanwhile, in Article 98 of The Act about Village, it is mentioned that the establishment of customary village should be made through local or district government regulations. Fourth, there is a misinterpretation about the term used especially the term "approval" and "establishment". The Forestry State Law concerning Indigenous law community uses the term establishment by approval, while Village The Act use the term the establishment of customary village through establishment.

In relation to the four points above, it seems that the term "establishment" is the most appropriate one to be used, not "approval".

9 The term used in Article 67 of the Act about Forestry and National Constitution Court Verdicts Number 35/PUU-X/2012.

10 The term used in Article 98 of the Act about Village. 
First, the term approval refers to an abstract legalization while the term establishment is more concrete than the term approval. The approval for indigenous law community does not need to be done since it has been stated in Article 18 B of the National Constitution 1945 and the Verdict of National Constitution Court which confirm the approval of indigenous law community. Second, the term establishment brings the concrete meaning of approving the existence of indigenous law community and this is regarded as a follow up of the National Constitution 1945 requirement. The establishment is a consequence of approval from state constitution and state laws. In this respect, approval has a higher norm compared with establishment. Thus, in the term establishment of indigenous law community, the meaning of approval has been included.

Other than the above, there is also a Regulation of Home Affair Ministry Number 52 Year 2014 concerning Guidance of Approving and Protecting Indigenous law community. In this regulation, the approval is made through a Regent/Mayor (Bupati/Wali Kota) decision letter. Article 6 point (2) states, "District Mayor makes a formal decision for approving and protecting law community based on the recommendations from local committees of law community". Point (3) further states, "If indigenous law community is located in two or more neighboring districts or regions, the approval or establishment can be made through combination decisions from related District Mayors".

The approval and protection through District Mayors, do not go in line with Forestry Regulation and the National Constitution Court Verdict Number 35. This is because, first, Home Affairs Ministry Regulation Number 52 Year 2014 is based on The Act Number 6 Year 2014. Second, in the Verdict of the National Constitution Court Number 35, the establishment of Indigenous law community is still made through District Government Regulations. Even, in Village Law, it is clearly stressed that the establishment of customary village (in which there is a indigenous law community) should be done through District Government Regulations. 


\section{E. Conclusions and Recommendations}

\section{Conclusions}

The settings of the existence of indigenous law community in the Act Number 41 Year 1999 about Forestry have given uncertainties to law community to manage and use forest in Indonesia. Meanwhile, the settings of this in the State Regulation Number 6 Year 2014 about Village provide an approval and specific management about customary village which is a part of Indigenous law community. In the State Regulation of Village, the establishment of Indigenous law community is done through regulations of provincial government.

The establishment of indigenous law community is done through provincial government regulations. This brings a bad consequence for indigenous forest; that is the management of indigenous forest by each indigenous law community becomes weak.

\section{Recommendations}

Based on the conclusions above, it is recommended that the Provincial government pursue local regulations to organize the establishment mechanism of indigenous law community. The area of indigenous forest be determined according to regulations about function transfer of forest area.

\section{Bibliography}

Aju, Ida et.al, 2003, Kemana Harus Melangkah? Masyarakat, Hutan, dan Perumusan Kebijakan di Indonesia, Jakarta: Yayasan Obor Indonesia.

Anonim, 2012, Profil Masyarakat Hukum Adat Marga Pembarap dan Bathin VIII di Provinsi Jambi, Kementerian Lingkungan Hidup RI.

Arizona, Yance, "Masyarakat Hukum Adat before the Constitutional Court: an Analyze on Paul Scholten's Interpretation Method in Contemporery Judicial Development in Indonesia," in http:/ / www.paulscholten.eu/research/article/ masyarakat-hukum- 
adat-before-the-constitutional-court/, accessed in May 2018.

Awang, S.A. 2002, Perencanaan Hutan Desa Secara Partisipatif. Workshop Perencanaan Hutan Desa Partisipatif, yang diselenggarakan Yayasan DAMAR \& PKHR UGM, 14 - 15 Agustus 2002 di Wisma Sargede Yogyakarta

Brutland, Gro Harlem et.al, 1998, Hari Depan Kita Bersama, Jakarta, Gramedia.

Campbell, J.Y., 2003, Beragam Pandangan Mengenai Kehutanan Masyarakat, edited by Ida Aju Pradnja Resosudarmo \& Corol J. Colfer., Jakarta: Yayasan Obor Indonesia.

Gadjong, Agussalim Andi, 2007, Pemerintahan Daerah: Kajian Politik dan Hukum, Bogor: Ghalia Indonesia.

Juliantara, D., 2002, Hutan Desa dan Pemerintahan Desa: Mencari Fomat Pengelolaan Hutan Desa, Situs Arupa.

Kartodiharjo, Hariadi \& Hir Jhamtani, 2006, Politik Lingkungan dan Kekuasaan di Indonesia, Jakarta: Equinox Publishing, . ., 1999, Masalah Kebijakan Pengelolaan Hutan Alam Produksi, Bagor: Pustaka Latin.

................ Hutan Negara di Dalam Wilayah Masyarakat Hukum Adat: Doktrin, Fakta dan Implikasinya Bagi Kelestarian Hutan, Bogor: Forestry Faculty, IPB.

Helmi, 20013, "Desa Kembali Ke sistem Lama, Mungkinkah? PSHKODA, Jambi Ekspres, Wednesday 16 July 2003.

..........., 2003, "Kebijakan Pengelolaan Hutan di Era Otonomi Daerah”, Forum Akademika, Fakultas Hukum Unja No. 20 Tahun X Edisi April.

.........., , 2012, Hukum Perizinan Lingkungan Hidup, Jakarta: Sinar Grafika

Manan, B., 2001, Menyongsong Fajar Otonomi Daerah, Yogyakarta: Pusat Studi Hukum (PSH) Fakultas Hukum UII.

Nurlinda, Ida, 2009, Prinsip-prinsip Pembaharuan Agraria; Perspektif Hukum, Jakarta: Rajawali Press.

Pilin, Matheus, 2002, Membedah Kehutanan Komunitas, Jogjakarta: Debut Press.

Salim, Emil, 1993, Pembangunan Berwawasan Lingkungan, Jakarta: 
LP3ES.

Sirait, Martua, Chip Fay dan A.Kusworo, 2000, Bagaimana Hak-Hak Masyarakat Hukum Adat Dalam Mengelola Sumber Daya Alam Diatur?, Lampung: ICRAF.

\section{Law and legislation}

Undang-undang Nomor 41 Tahun 1999 tentang Kehutanan / the Act Number 41 Year 1999 on Forestry.

Undang-undang Nomor 23 Tahun 2014 tentang Pemerintahan Daerah / the Act Number 23 Year 2014 on Regional Governance.

Undang-undang Nomor 12 Tahun 2011 tentang Pembentukan Peraturan Perundang-Undangan / the Act Number 12 Year 2011 on the Making of Rules and Laws. 